\title{
Toxicity Studies of Aqueous and Ethanolic Extracts of Fermented Seeds of Parkia biglobosa (Mimosaceae) in Rats
}

\author{
Coulibaly Seydou Ouolouho' ${ }^{1}$, Ouattara Abou², Ouattara \\ Karamoko ${ }^{1}$, Coulibaly Adama ${ }^{1}$
}

\begin{abstract}
${ }^{1}$ Laboratory of Pharmacodynamics-biochemical, Faculty of Biosciences, Félix Houphouët-Boigny University, 22 PO Box 582 Abidjan 22 (Côte d'Ivoire)

${ }^{2}$ Department of Biochemistry-microbiology, Jean Lorougnon Guédé University, PO Box 150 Daloa (Côte d'Ivoire)

Abstract: Parkia biglobosa is a medicinal plant that is used in the traditional treatment of various pathologies. The fermented seeds of this plant «néré » are used commonly in the treatment of high blood pressure. In order to establish the safety of these, acute and subacute toxicity tests were performed. For this purpose, hematological and biochemical parameters were determined in rats after repeated dosing of 1000, 2000, 3000, 4000 and $5000 \mathrm{mg} / \mathrm{kg}$ body weight (bw) of the aqueous and ethanolic extracts of the fermented seeds of $P$. biglobosa for 28 days. The resulting $\mathrm{LD}_{50}$ is greater than $5000 \mathrm{mg} / \mathrm{kg}$ bw and the extracts have no effect on most of the measured blood parameters. This study revealed that extracts of the fermented seeds of Parkia biglobosa are non-toxic at all doses tested and have immunostimulant and analgesic activity.
\end{abstract}

Keywords: Parkia biglobosa, Toxicity, Blood Parameters, High Blood Pressure

\section{Introduction}

Parkia is a pantropical genus of the family Fabaceae (Aubréville, 1950 ; Arbonnier, 2002) which includes 34 species distributed in South America (18 species), Asia (12 species) and Africa (4 species including one in Madagascar) (Hopkins, 1986; Luckow and Hopkins, 1995 ; Luckow, 2005). P. biglobosa is a species of this genus and is commonly used in medicine and traditional pharmacopoeia (Ouédraogo, 1995). All parts of this plant are used as a main recipe or in combination with other plants for the care of various ailments (Bonnah et al., 1998). In fact, the different parts of P. biglobosa are used for the treatment of dermatoses, hypertension and haemorrhage (Odetola, 2006; Kanko, 2000 ; Kouadio, 2000 ; Tringali, 2000). Thus, the leaves are used to treat eye infections, skin lesions and leprosy (Erakhrumen et al., 2010). They are also involved in the care of febrile states (Aubréville, 1950). Bark is used for the treatment of trypanosomiasis, ulcer, fever and for the care of wounds (Osho and Lajide, 2012). Roots are used to treat infertility, hypertension, stomach upset and are also used as an anti-poison (Lawal et al, 2010, Erakhrumen et al, 2010). In addition, the fermented seeds of $P$. biglobosa serve as food condiments for various peoples.
These fermented seeds are called «afitin »in Benin (Azopkota et al., 2011), "dawa-dawa or iru » in Nigeria, «nététu »in Senegal and «soumbala »in Mali (N'Dir et al., 1994). In Côte d'Ivoire, this condiment is called in malinké «soumara» and is considered to have antihypertensive properties according to its consumers. The aim of this work is to study the toxicity of aqueous and ethanolic extracts of fermented seeds of $P$. biglobosa in rat.

\section{MATERIALS AND METHODS}

\begin{abstract}
Materials
Plant Materials

According to N'Dir et al., (1994), the fermented seeds of Parkia Biglobosa (soumara) were obtained by essential stages. The first cooking of raw seeds is long. It lasts 15 to 24 hours and its purpose is to soften the seminal integument. After this first essential step, the seeds are dehulled and washed with water and then undergo a second cooking time shorter than the first (one to two hours of time). Finally, the almonds are dewatered, sorted and fermented at the bottom of a canary covered at 28 to $40^{\circ} \mathrm{C}$ for three days. The fermented seeds are finally recovered and dried in the sun to obtain the soumara.
\end{abstract}




\section{Experimental animals}

Male and female albino white rats of Wistar strains weighing between $180 \mathrm{~g}$ and $250 \mathrm{~g}$ were used for the study.

\section{Methods \\ Preparation of plant extracts}

Two (02) samples of $500 \mathrm{~g}$ of soumara were dried at room temperature in the laboratory, then crushed and powdered in a mortar. Subsequently, $250 \mathrm{~g}$ of soumara powder were dissolved in $500 \mathrm{~mL}$ of distilled water and then homogenized with magnetic stirring for 24 hours at $25^{\circ} \mathrm{C}$ using a magnetic stirrer. The homogenate obtained was filtered successively twice on hydrophilic cotton and then once on Whatmann filter paper. The filtrate obtained is evaporated using a Med Center Venticell type oven at $50^{\circ} \mathrm{C}$. to give a powder which constitutes the aqueous extract. The same operation was carried out using instead of distilled water of ethanol $70 \%$. However, the volume of the hydro-alcoholic filtrate obtained is first reduced using a Buchi-type rotary evaporator at a temperature of $60^{\circ} \mathrm{C}$. Then, the remainder of the filtrate is evaporated using a Med Center Venticell type oven at $50^{\circ} \mathrm{C}$. to give a powder which represents the $70 \%$ ethanol extract. All the vegetable raw extracts thus formed are stored in the refrigerator until 'to their use for different tests.

\section{Acute toxicity}

The acute toxicity study was performed on Wistar rats. The experiment was conducted sequentially according to OECD guideline 423 (2001) with predefined doses of 1000, 3000 and $5000 \mathrm{mg} / \mathrm{kg}$ bw. Each stage of the experiment required the use of three rats. 12 rats with comparable weights are divided into 4 lots of 3 rats. The animals were acclimatized at least 5 days to laboratory conditions before the start of the experiment. They were fasted all night before administering the different doses, but they had access to water. Acute toxicity was assessed by increasing oral doses of the extracts. The different lots of rats received respectively 1000,3000 and $5000 \mathrm{mg} / \mathrm{kg}$ bw at a rate of $1 \mathrm{~mL} / \mathrm{rat}$. The experimental protocol was as follows: first, the first batch of rats received the single dose of $1000 \mathrm{mg} / \mathrm{kg}$ bw. Then, they were observed with special attention during the first hours after the force-feeding then during the 24 hours. The observation of the animals continued for 14 days. The absence of mortality observed with the animals of the first batch allowed to always administer by gavage the higher dose which is $3000 \mathrm{mg} / \mathrm{kg}$ bw in the second batch. And finally, the last batch received the limit dose of $5000 \mathrm{mg} / \mathrm{kg}$ bw. The control group received distilled water.

\section{Subacute toxicity}

OECD Guideline 407 (2006) for the testing of chemicals, with some modifications, was used for this study. The test substance is administered orally (gavage) at different dose levels to several batches of animals at a dose level per batch for a period of 28 days. 33 healthy adult rats were randomly assigned to 11 batches of three rats. They were placed in the cages at least five days before the start of the study, to allow them to acclimatize to laboratory conditions. They received by gavage for 28 days the doses of $1000,2000,3000,4000$ and $5000 \mathrm{mg} / \mathrm{kg}$ bw of the aqueous and ethanolic extracts. The volume of extract administered every three days in a single dose was 1 $\mathrm{mL}$ per $100 \mathrm{~g}$ bw. The control group received distilled water. During the 28 days of treatment, the animals were observed daily for clinical signs (lack of appetite, convulsions, drowsiness, etc.).

Before the start of the experiment, all the rats were weighed and then twice a week during the treatment period to determine the impact of the extracts on the weight growth of the animals.

After 28 days of gavage, the rats were anesthetized with ether, the blood is taken early in the morning by the technique of amputation at the end of the tail (5 $\mathrm{mm}$ from the tip) previously disinfected with $96^{\circ}$ ethanol and heated to cause vasodilation.

Hematologic analysis was performed using a Sysmex KX-21 Automated Hematology Analyzer (Canada) according to the manufacturer's instruction manual with appropriate reagents (kits).

For assays of the biochemical parameters, the contents in the dry tubes were centrifuged with a centrifuge at $3000 \mathrm{rpm}$ for 5 minutes. The serum obtained is collected and stored at $-20^{\circ} \mathrm{C}$ for the analysis of serum markers of the kidney, liver and heart using the COBAS INTEGRA 400 plus analyzer (France). The protocol for each assay was preestablished and then incorporated into the device during assays according to the manufacturer's instruction manual with the appropriate reagents (kits).

\section{Statistical analysis}

The statistical analysis of all the results expressed in means accompanied by the standard deviations (Mean \pm ET), was carried out according to the analysis of the variances (ANOVA ONE WAY). When there are more than two samples to be analyzed, an appropriate analysis of variance (ANOVA) should be used. One-way (univariate) ANOVA followed by Tukey was chosen. Differences between averages were determined using the Tukey Multiple Comparison Test using Graph Pad Prism 5.0 (Microsoft U.S.A). These differences are considered significant when $\mathrm{p}<0.05$. 


\section{RESULTS}

\section{Acute toxicity}

At the dose of $1000 \mathrm{mg} / \mathrm{kg}$ bw, the rats showed no signs of toxicity after administration of the extracts. There is no change in mobility, behavior, appetite. No mortality was observed. These observations were made after three hours and for 14 days after administration of the product. At the dose of $3000 \mathrm{mg}$ $/ \mathrm{kg}$ bw, the rats drag the forelegs. They are tired with a feeling of thirst. This state is very accentuated with the ethanolic extract. However, there were no deaths. After heavy water consumption, the signs mentioned disappear. At a dose of $5000 \mathrm{mg} / \mathrm{kg} \mathrm{bw}$, the animals are very exhausted and weakened but return to normal two to three days later.

\section{Subacute toxicity \\ Effect on weight}

Aqueous and ethanolic extracts did not significantly affect weight gain in rats fed during the 28 day period.

\section{Effect on hematological parameters}

The results of the blood count show that at doses of 3000,4000 and $5000 \mathrm{mg} / \mathrm{kg}$ bw, ethanolic and aqueous extracts lead to a significant increase ( $P$ $<0.05)$ in white blood cells, platelets and total lymphocyte levels in treated animals compared to control animals. However, no significant variation was observed for red blood cells (RBCs) and afferents (Hb, HCTE, VGM, and MCHC) (Tables 1 and 2).

\section{Effect on biochemical parameters}

The results indicate that aqueous and ethanolic extracts do not significantly influence most biochemical parameters except creatinine and urea. In fact, at doses ranging from 2000 to $5000 \mathrm{mg} / \mathrm{kg}$ bw, these extracts significantly modify the concentrations of urea and creatinine in the blood. At the dose of $5000 \mathrm{mg} / \mathrm{kg}$ bw with the ethanolic extract, the concentrations rose from $0.33 \mathrm{~g} / \mathrm{l}$ for urea to $1.67 \mathrm{~g} / \mathrm{l}$, respectively. The concentration of creatinine has also increased from $21.90 \mathrm{~g} / \mathrm{l}$ to $51.68 \mathrm{~g} / \mathrm{l}$. In contrast, with the aqueous extract at this same dose (5000 $\mathrm{mg} / \mathrm{kg} \mathrm{bw}$ ), the concentrations of urea and creatinine were respectively $1.10 \mathrm{~g} / \mathrm{l}$ and $48.58 \mathrm{~g} / \mathrm{l}$ (Tables 3 and 4).

\section{Discussion}

The acute toxicity study revealed that gavage administration of aqueous and ethanolic extracts resulted in no mortality in animals up to the limit dose of $5000 \mathrm{mg} / \mathrm{kg}$ bw. Studies of Parkia biglobosa bark extracts yielded similar results (Builders et al., 2012). According to OECD test Guideline 423, the aqueous and ethanol extracts of fermented seeds of $P$. biglobosa have a lethal dose of $50\left(\mathrm{LD}_{50}\right)$ greater than
$5000 \mathrm{mg} / \mathrm{kg}$ bw. The aqueous and ethanolic extracts of this condiment are therefore classified as non-toxic substances orally according to the classification of Hodge and Sterner (1943). This method does not allow a precise value of the $\mathrm{LD}_{50}$ to be defined, but it serves as a suggestion for the classification of the crude extract on the basis of the prediction of the dose at which the animals must survive (Roopashree et al., 2009). Clinical signs of feverishness observed at high doses of the extracts during acute toxicity are not due to toxicity of the extracts but rather signs related to hypotension. According to the study by Coulibaly et al (2017), the fermented seeds of $P$. biglobosa have a hypotensive effect. Hypotension would therefore be responsible for elevating serum urea and creatinine levels at high doses of the extracts in the subacute toxicity study. In fact, creatinine and urea are essentially eliminated from the blood by glomerular filtration, which is itself dependent on the arterial pressure in the capillaries. A decrease in this pressure of $10 \mathrm{mmHg}$ causes a significant decrease in plasma volume by the glomerulus, and therefore a decrease in glomerular filtration (Doumbia et al., 2007).

The subacute toxicity study revealed that hepatic function was well preserved during the 28 days of oral administration of the extracts, indicated by serum AST and ALT levels that are comparable to the control values. These enzymes are the markers of the liver, their activities increase in cases of hepatic toxicity (Rahman et al., 2001 ; Hilaly et al., 2004). Also, the determination of the plasma total protein level can provide information on the capacity of synthesis of the liver (Rasekh et al., 2008). Thus, plasma protein levels unchanged in the treated groups compared to the control group therefore suggest an absence of any abnormality in the liver's synthetic capacity.

The evaluation of the hematological parameters showed that the extracts at the different doses had no significant effect on the red blood cells and the afferent indices ( $\mathrm{Hb}, \mathrm{MCHC}, \mathrm{MCV}$ and HCTE) during the experimental period, which indicates that There was no destruction, no problems with maturity, and no change in red blood cell production rate (erythropoiesis) (Udut et al., 2005). It also shows that the extracts do not have the potential to stimulate erythropoiesis which is the humoral regulator of red blood cell production (Sanchez-Elsner et al., 2004). However, the extracts at doses of 3000 to $5000 \mathrm{mg} / \mathrm{kg}$ bw had significant effects on the numbers of white blood cells, blood platelets and the lymphocyte count while there were no infections.

These extracts therefore seem to have the possibility of stimulating the immune system. Studies by Yapo et al., (2011) also showed the immunostimulatory 
effect of aqueous extracts of $P$. biglobosa leaves. The extracts tested also have analgesic effects because the animals manage to withstand hypotension despite the high doses administered and do not die. Kouadio et al. (2000) also showed the analgesic and antiinflammatory effects of alcoholic extracts of $P$. biglobosa.

Glucose levels did not change significantly during treatment compared to the control group, suggesting that the extracts did not affect the blood glucose control system.

\begin{tabular}{|c|c|c|c|}
\hline \multicolumn{4}{|c|}{$\begin{array}{l}\text { Also, the extracts did not significantly alter the seru } \\
\text { values of HDL (high density lipoprotein), LDL (lo } \\
\text { density lipoprotein), total cholesterol } \\
\text { triglycerides. However, a slight decrease in LD } \\
\text { levels and a slight increase in HDL levels a } \\
\text { observed compared to the control group. The increa } \\
\text { in HDL, also known as good cholesterol, is } \\
\text { protective factor for the heart muscle (HAS, 2005 } \\
\text { but also has a beneficial effect against cardiovascul } \\
\text { complications such as atherosclerosis. Néré see } \\
\text { could therefore prevent cardiovascular complication } \\
\text { nented seeds on hematological parameters in rat }\end{array}$} \\
\hline & Eth $\mathbf{3 0 0 0}$ & Eth 4000 & Eth 5000 \\
\hline & $9,485 \pm 0,02^{b}$ & $9,840 \pm 0,04^{b}$ & $10,175 \pm 0,05^{b}$ \\
\hline & & & \\
\hline & $768 \pm 15,50^{b}$ & $783,5 \pm 18,50^{b}$ & \\
\hline & $13,54 \pm 0,02^{b}$ & $13,86 \pm 0,04^{b}$ & $14,03 \pm 0,08^{b}$ \\
\hline & $56,38 \pm 3,38^{\mathrm{a}}$ & $56.32 \pm 1,38^{\mathrm{a}}$ & $56,62 \pm 0,49^{\mathrm{a}}$ \\
\hline & $29,52 \pm 0,02^{\mathrm{a}}$ & $29,81 \pm 0,35^{\mathrm{a}}$ & $28,62 \pm 0,05^{\mathrm{a}}$ \\
\hline & & $14,29 \pm 0,15^{b}$ & $14,27 \pm 0,56$ \\
\hline & $33,55 \pm 0,32^{\mathrm{a}}$ & $33,13 \pm 0,30^{\mathrm{a}}$ & \\
\hline
\end{tabular}

Data are expressed as mean \pm SEM; $(n=3)$; a: non-significant difference $(p>0.05)$ compared to the rats of the control group and $b$ : significant difference $(p<0.05)$ compared to the rats of the control group. Comparisons are made on the lines. WBC: White blood cells $\left(x 10^{3} / \mu L\right) ; R B C:$ Red blood cells $\left(x 10^{6} / \mu L\right) ;$ PLTS: Platelets $\left(x 10^{3} / \mu L\right)$; LYM: Lymphocyte (\%), MCV: Mean cell volume (FL/cell), HCTE: Hematocrit (\%); Hb: Hemoglobin (g/dL), MCHC: Mean corpuscular hemoglobin concentration ( $g / d L)$.

Table 2 : Effect of aqueous extract of $P$. biglobosa fermented seeds on hematological parameters in rat

\begin{tabular}{|c|c|c|c|c|c|c|}
\hline $\begin{array}{c}\text { hematological } \\
\text { parameters }\end{array}$ & Control & Aqx 1000 & Aqx 2000 & $A q \times 3000$ & $\operatorname{Aqx} 4000$ & Aqx 5000 \\
\hline WBC $\left(\times 10^{3} / \mu \mathrm{L}\right)$ & $8,715 \pm 0,27$ & $8,505 \pm 0,39^{\mathrm{a}}$ & $8,609 \pm 0,33^{a}$ & $9,301 \pm 0,01^{b}$ & $9,570 \pm 0,04^{b}$ & $9,221 \pm 0,17^{b}$ \\
\hline $\mathbf{R B C}\left(\times 10^{6} / \mu \mathrm{L}\right)$ & $7,375 \pm 0,26$ & $7,41 \pm 0,02^{\mathrm{a}}$ & $7,68 \pm 0,07^{\mathrm{a}}$ & $7,60 \pm 0,03^{\mathrm{a}}$ & $7,60 \pm 0,21^{\mathrm{a}}$ & $7,66 \pm 0,32^{\mathrm{a}}$ \\
\hline $\operatorname{PLTS}\left(\times 10^{3} / \mu \mathrm{L}\right)$ & $648,5 \pm 10,50$ & $649,11 \pm 6,5^{\mathrm{a}}$ & $667,01 \pm 3,3^{\mathrm{a}}$ & $788,12 \pm 4,9^{b}$ & $761,13 \pm 7,1^{b}$ & $765,3 \pm 4,5^{b}$ \\
\hline LYM (\%) & $12,34 \pm 0,21$ & $12,55 \pm 0,05^{\mathrm{a}}$ & $12,77 \pm 0,27^{\mathrm{a}}$ & $12,93 \pm 0,11^{\mathrm{a}}$ & $13,57 \pm 0,08^{b}$ & $13,38 \pm 0,14^{b}$ \\
\hline MCV (Fl/cell) & $52,64 \pm 3,49$ & $57,66 \pm 5,10^{\mathrm{a}}$ & $52,50 \pm 4,21^{\mathrm{a}}$ & $58,01 \pm 2,28^{\mathrm{a}}$ & $53,74 \pm 5,77^{\mathrm{a}}$ & $55,88 \pm 1,01^{2}$ \\
\hline HCTE (\%) & $28,23 \pm 0,25$ & $29,71 \pm 0,41^{\mathrm{a}}$ & $29,85 \pm 0,52^{\mathrm{a}}$ & $29,55 \pm 0,33^{\mathrm{a}}$ & $28,91 \pm 0,35^{\mathrm{a}}$ & $29,13 \pm 0,17^{3}$ \\
\hline Hb $(\mathrm{g} / \mathrm{dL})$ & $13,39 \pm 0,86$ & $13,57 \pm 0,23^{\mathrm{a}}$ & $13,69 \pm 0,78^{a}$ & $13,42 \pm 0,49^{a}$ & $13,63 \pm 0,37^{\mathrm{a}}$ & $13,58 \pm 0,88^{3}$ \\
\hline $\mathrm{MCHC}(\mathrm{g} / \mathrm{dL})$ & $32,82 \pm 0,67$ & $32,93 \pm 0,18^{\mathrm{a}}$ & $32,73 \pm 0,34^{\mathrm{a}}$ & $32,86 \pm 0,74^{\mathrm{a}}$ & $32,89 \pm 0,61^{\mathrm{a}}$ & $33,29 \pm 0,39^{3}$ \\
\hline
\end{tabular}

Data are expressed as mean \pm SEM; $(n=3)$; a: non-significant difference $(p>0.05)$ compared to the rats of the control group and $b$ : significant difference $(p<0.05)$ compared to the rats of the control group. Comparisons are made on the lines. WBC: White blood cells $\left(x 10^{3} / \mu L\right) ;$ RBC: Red blood cells $\left(x 10^{6} / \mu L\right) ;$ PLTS: Platelets $\left(x 10^{3} / \mu L\right)$; LYM: Lymphocyte (\%), MCV: Mean cell volume (FL/cell), HCTE: Hematocrit (\%); Hb: Hemoglobin (g/dL), $M C H C$ : Mean corpuscular hemoglobin concentration $(\mathrm{g} / \mathrm{dL})$.

Table 3 : Effect of ethanolic extract of $P$. biglobosa fermented seeds on biochemical parameters in rat

\begin{tabular}{|c|c|c|c|c|c|c|}
\hline $\begin{array}{c}\text { biochemical } \\
\text { parameters }\end{array}$ & Control & Eth 1000 & Eth 2000 & Eth 3000 & Eth 4000 & Eth 5000 \\
\hline UREA $(\mathrm{g} / \mathrm{L})$ & $0,3300 \pm 0,04$ & $0,3400 \pm 0,05^{\mathrm{a}}$ & $0,60 \pm 0,14^{b}$ & $1,01 \pm 0,02^{b}$ & $1,20 \pm 0,05^{b}$ & $1,67 \pm 0,01^{b}$ \\
\hline CREATININE ( $(\mathrm{g} / \mathrm{L})$ & $21,90 \pm 0,25$ & $23,11 \pm 0,48^{\mathrm{a}}$ & $27,96 \pm 0,74^{b}$ & $46,25 \pm 0,18^{b}$ & $49,85 \pm 0,28^{b}$ & $51,68 \pm 0,99^{b}$ \\
\hline $\operatorname{GLY}(\mathrm{g} / \mathrm{L})$ & $0,6650 \pm 0,02$ & $0,6800 \pm 0,01^{\mathrm{a}}$ & $0,690 \pm 0,03^{\mathrm{a}}$ & $0,70 \pm 0,02^{\mathrm{a}}$ & $0,690 \pm 0,010^{\mathrm{a}}$ & $0,665 \pm 0,01^{\mathrm{a}}$ \\
\hline LDH (UI/L) & $140,0 \pm 1,00$ & $138,5 \pm 0,50^{\mathrm{a}}$ & $139,0 \pm 1,50^{\mathrm{a}}$ & $139,5 \pm 0,7^{\mathrm{a}}$ & $137,5 \pm 0,7^{\mathrm{a}}$ & $137,0 \pm 1,50^{\mathrm{a}}$ \\
\hline $\mathrm{HDL}(\mathrm{mmol} / \mathrm{L})$ & $1,490 \pm 0,030$ & $1,505 \pm 0,13^{\mathrm{a}}$ & $1,498 \pm 0,01^{\mathrm{a}}$ & $1,570 \pm 0,04^{\mathrm{a}}$ & $1,533 \pm 0,02^{\mathrm{a}}$ & $1,520 \pm 0,01^{\mathrm{a}}$ \\
\hline $\mathrm{LDL}(\mathrm{mmol} / \mathrm{L})$ & $2,160 \pm 0,02$ & $2,145 \pm 0,02^{\mathrm{a}}$ & $2,165 \pm 0,02^{\mathrm{a}}$ & $2,155 \pm 0,02^{\mathrm{a}}$ & $2,180 \pm 0,01^{\mathrm{a}}$ & $2,165 \pm 0,03^{\mathrm{a}}$ \\
\hline CHOL $(\mathrm{mmol} / \mathrm{L})$ & $2,555 \pm 0,03$ & $2,495 \pm 0,09^{\mathrm{a}}$ & $2,635 \pm 0,21^{\mathrm{a}}$ & $2,595 \pm 0,02^{\mathrm{a}}$ & $2,525 \pm 0,25^{\mathrm{a}}$ & $2,525 \pm 0,02^{\mathrm{a}}$ \\
\hline TG $(\mathrm{mmol} / \mathrm{L})$ & $1,140 \pm 0,02$ & $1,125 \pm 0,02^{\mathrm{a}}$ & $1,175 \pm 0,01^{\mathrm{a}}$ & $1,150 \pm 0,04^{\mathrm{a}}$ & $1,185 \pm 0,01^{\mathrm{a}}$ & $1,165 \pm 0,02^{\mathrm{a}}$ \\
\hline ALT (U/L) & $59,84 \pm 2,11$ & $61,67 \pm 2,16^{\mathrm{a}}$ & $62,20 \pm 2,93^{\mathrm{a}}$ & $57,73 \pm 4,27^{\mathrm{a}}$ & $62,58 \pm 4,44^{\mathrm{a}}$ & $60,85 \pm 5,12^{\mathrm{a}}$ \\
\hline AST (U/L) & $193,43 \pm 4,33$ & $197,68 \pm 3,13^{\mathrm{a}}$ & $193,34 \pm 5,10^{\mathrm{a}}$ & $194,25 \pm 5,21^{\mathrm{a}}$ & $195,11 \pm 7,14^{\mathrm{a}}$ & $196,25 \pm 5,29^{\mathrm{a}}$ \\
\hline $\mathrm{TP}(\mathrm{g} / \mathrm{L})$ & $68,55 \pm 1,21$ & $68,67 \pm 1,32^{\mathrm{a}}$ & $69,02 \pm 1,23^{\mathrm{a}}$ & $67,79 \pm 1,87^{\mathrm{a}}$ & $69,35 \pm 2,25^{\mathrm{a}}$ & $67,88 \pm 2,01^{\mathrm{a}}$ \\
\hline
\end{tabular}

Data are expressed as mean \pm SEM; $(n=3)$; (a: non-significant difference $(p>0.05)$ compared to the rats of the control group and $b$ : significant difference ( $p>0.05)$ compared to the control group). Comparisons are made on the lines. GLY : Blood Glucose (g/L), LDH: Lactate dehydrogenase (mmol/L); HDL: High density lipoproteins 
(mmol/L); LDL: Low density lipoproteins (mmol/L); CHOL : Cholesterol (mmol/L), TG: Triglycerides (mmol/l), ALT: Alanine transaminase (U/L); AST: aspartate transaminase (U/L); TP : Total protein (g/L).

Table 4 : Effect of aqueous extract of $P$. biglobosa fermented seeds on biochemical parameters in rat

\begin{tabular}{|c|c|c|c|c|c|c|}
\hline $\begin{array}{l}\text { biochemical } \\
\text { parameters }\end{array}$ & Control & Aqx 1000 & Aqx 2000 & Aqx 3000 & Aqx 4000 & Aqx 5000 \\
\hline UREA $(\mathrm{g} / \mathrm{L})$ & $0,3300 \pm 0,04$ & $0,3500 \pm 0,07^{\mathrm{a}}$ & $0,4900 \pm 0,21^{b}$ & $0,6200 \pm 0,0^{b}$ & $0,9500 \pm 0,33^{b}$ & $1,10 \pm 0,17^{\mathrm{b}}$ \\
\hline CREATININE (g/L) & $21,90 \pm 0,25$ & $22,13 \pm 0,45^{\mathrm{a}}$ & $23,59 \pm 0,27^{\mathrm{a}}$ & $39,55 \pm 0,31^{b}$ & $43,87 \pm 0,52^{b}$ & $48,58=0,18^{b}$ \\
\hline GLY $(g / L)$ & $0,6650 \pm 0,02$ & $0,680 \pm 0,03^{\mathrm{a}}$ & $0,6667 \pm 0,04^{\mathrm{a}}$ & $0,6803 \pm 0,05^{\mathrm{a}}$ & $0,6807 \pm 0,07^{\mathrm{a}}$ & $0,6803 \pm 0,03^{\mathrm{a}}$ \\
\hline LDH (UI/L) & $140,0 \pm 1,00$ & $138,7 \pm 0,60^{\mathrm{a}}$ & $139,2 \pm 1,25^{\mathrm{a}}$ & $138,5 \pm 0,2^{\mathrm{a}}$ & $139,5 \pm 0,6^{\mathrm{a}}$ & $138,6 \pm 0,3^{\mathrm{a}}$ \\
\hline $\mathrm{HDL}(\mathrm{mmol} / \mathrm{L})$ & $1,490 \pm 0,030$ & $1,523 \pm 0,22^{\mathrm{a}}$ & $1,505 \pm 0,53^{\mathrm{a}}$ & $1,568 \pm 0,22^{\mathrm{a}}$ & $1,517 \pm 0,51^{\mathrm{a}}$ & $1,511 \pm 0,29^{\mathrm{a}}$ \\
\hline $\mathrm{LDL}(\mathrm{mmol} / \mathrm{L})$ & $2,160 \pm 0,02$ & $2,153 \pm 0,05^{\mathrm{a}}$ & $2,158 \pm 0,06^{\mathrm{a}}$ & $2,155 \pm 0,03^{\mathrm{a}}$ & $2,162 \pm 0,7^{\mathrm{a}}$ & $2,159 \pm 0,06^{\mathrm{a}}$ \\
\hline CHOL $(\mathrm{mmol} / \mathrm{L})$ & $2,555 \pm 0,03$ & $2,498 \pm 0,05^{\mathrm{a}}$ & $2,502 \pm 0,07^{\mathrm{a}}$ & $2,591 \pm 0,09^{\mathrm{a}}$ & $2,488 \pm 0,04^{\mathrm{a}}$ & $2,503 \pm 0,03^{\mathrm{a}}$ \\
\hline $\mathrm{TG}(\mathrm{mmol} / \mathrm{L})$ & $1,140 \pm 0,02$ & $1,135 \pm 0,03^{\mathrm{a}}$ & $1,135 \pm 0,02^{\mathrm{a}}$ & $1,145 \pm 0,06^{\mathrm{a}}$ & $1,147 \pm 0,05^{\mathrm{a}}$ & $1,147 \pm 0,07^{\mathrm{a}}$ \\
\hline ALT (U/L) & $59,84 \pm 2,11$ & $58,85 \pm 3,16^{\mathrm{a}}$ & $60,20 \pm 1,34^{\mathrm{a}}$ & $59,65 \pm 1,55^{\mathrm{a}}$ & $61,45 \pm 2,04^{\mathrm{a}}$ & $68,66 \pm 2,23^{\mathrm{a}}$ \\
\hline AST (U/L) & $193,43 \pm 4,33$ & $194,33 \pm 6,32^{\mathrm{a}}$ & $197,87 \pm 4,75^{\mathrm{a}}$ & $195,15 \pm 3,62^{\mathrm{a}}$ & $198,53 \pm 2,13^{\mathrm{a}}$ & $196,91 \pm 7,23^{\mathrm{a}}$ \\
\hline $\mathrm{TP}(\mathrm{g} / \mathrm{L})$ & $68,55 \pm 1,21$ & $69,45 \pm 1,72^{\mathrm{a}}$ & $67,89 \pm 2,38^{\mathrm{a}}$ & $69,33 \pm 1,12^{\mathrm{a}}$ & $69,26 \pm 1,66^{\mathrm{a}}$ & $68,90 \pm 1,59^{\mathrm{a}}$ \\
\hline
\end{tabular}

Data are expressed as mean \pm SEM; $(n=3)$; (a: non-significant difference $(p>0.05)$ compared to the rats of the control group and $b$ : significant difference ( $>$ > 0.05) compared to the control group). Comparisons are made on the lines. GLY: Blood Glucose (g/L), LDH: Lactate dehydrogenase $(\mathrm{mmol} / \mathrm{L})$; HDL: High density lipoproteins $(\mathrm{mmol} / \mathrm{L})$; LDL: Low density lipoproteins (mmol/L); CHOL : Cholesterol $(\mathrm{mmol} / \mathrm{L})$, TG: Triglycerides (mmol/l), ALT: Alanine transaminase (U/L); AST: aspartate transaminase (U/L); TP : Total protein (g/L).

\section{Conclusion}

Acute and subacute toxicity tests of aqueous and ethanolic extracts of Parkia biglobosa fermented seeds by the oral route showed no toxic effect on animals at the tested doses. Indeed, no case of poisoning is known for this condiment from consumers. This result seems to be in favor of its use in the treatment of high blood pressure. Also, this condiment has an immunostimulant and analgesic effect, which could be beneficial for consumers.

\section{References}

1. Aubréville A., 1950. Flore forestiére soudano-guinéenne. A.O.F-CAMEROUN-AEF, 523p.

2. Arbonnier M., 2002. Arbuste et lianes de zones séches d'Afriques de l'Ouest. CIRAD. MNHN.IUCN, 573p.

3. Azokpota P., Houngbo H.Y., Akissoe N.H., 2011. Aptitude stabilisatrice des conservateurs traditionnels de l'afitin, un condiment africain à base de graines de néré (Parkia biglobosa Jack.P.Br). cah Agric 20 : 495, 494-499.

4. Bonnah H., Akikokou K. A., Akpagana K., Gbeassor M., 1998. Contribution à l'étude des propriétés pharmacologique des extraits hydro-alcooliques des graines de Parkia biglobosa. Sciences et Médecines, 00 : 12-15pp.

5. Builders M. I., Isichie C. O. et Aguiyi J. C., 2012. Toxicity Studies of the Extracts of Parkia biglobosa Stem Bark in Rats. British Journal of Pharmaceutical Research, 2(1) : 116.

6. Campbell-Platt G., 1980 African locust bean (Parkia species) and its wet African fermented food product, dawadawa. Ecology of food and Nutrition 9, 123-132.

7. Coulibaly S. O., Ouattara A., Ouattara K., Coulibaly A., 2017. Effets antihypertensifs des extraits aqueux et éthanolique des graines fermentées de Parkia biglobosa (Mmimosaceae) chez les rats. European Scientific Journal, 13(36) : 162-176.

8. Diawara B., Konaté J., Kanwe, 2004. Rapport d'activité : Formation des femmes en technologie améliorée de production du soumbala. PAMER. Ouagadougou. $18 \mathrm{p}$.

9. Diawara B., Sawadogo L., W. Amoa-Awua et M. Jakobsen., 1997. Valorisation technologique et nutritionnelle du néré ou Parkia biglobosa (Jacq.) benth : une espéce agroforestiére. Ouagadougou, Burkina-Faso. 173 p.

10. Doumbia I. Q., Adebo I. B., Coulibaly G. F., Gue G. F., Djaman A. J., 2007. Variation du taux sérique de l'urée et créatinine chez des lapins traités par Mareya micrantha. Journal. Science of pharmacology and biology, $8: 6-13$.
11. Erakhrumen A., Ogunsanwo O. \& Ajewole O., 2010. Assessment of some other traditional uses of accepted agroforestry fuelwood species in Akinyele and Ido loca government areas, Oyo State, Nigeria. IJSF ; 3(1) : 47- 65.

12. Gutierrez M.L., Maizi P., Nago C.M., Hounhouigan D.J., 2000. Production et commercialisation de l'afitin dans la région d'Abomey-Bohicon au Bénin. Montpellier : CERNA, Cnearc, Cirad.

13. HAS, 2005b. - Service des recommandations professionnelles : Prise en charge des patients adultes atteints d'hypertension sanguine artérielle essentielle. Actualisation 2005. Paris, 26p. Accessible sur http://www.has-sante.fr. Consulté le 06 mai 2017.

14. Hilaly J.E., Israili Z.H. \& Lyouss B., 2004. - Acute and chronic toxicological studies of Ajuva iva in experimental animals. J. Ethnopharmacol., 91: 43-50.

15. Hodge A \& Sterner B., 1943. - Determination of substances acute toxicity by LD50.B50. Amer. Industrial Hyg. Assoc., $10: 93-96$.

16. Hopkins HC., 1983. The taxonomy reproductive biology and economic potential of Parkia (leguminosae : Mimosoideae) in Africa and Madagascar. Botanical Journal of the Linnean Society $87: 135-167 \mathrm{pp}$.

17. Hopkins HC., 1986. Parkia (Leguminoseae : Mimosoideae). Flora Neotropica Monograph, 43 :1-124pp.

18. Hopkins HC., 1984. Floral biology and pollinisation ecology of the Neotropical species of Parkia. Journal of Ecology $72: 1-23$ pp.

19. Hopkins HC et White F., 1984. The ecology and chorology of Parkia in Africa. Bulletin du Jardin Botanique National de Belgique Bulletin National Plantentuin, 54 : 235-266 pp.

20. Jaffe M., 1886. - Ueber den Niederschlag welchen Pikrinsäure in normalen und über eine Harn erzeugt neue reaction Kreatinins. Z Physiol Chem, 10: 39 - 400.

21. Johnson D. W., Jones G. R., Mathew T. H., Ludlow M. J., Doogue M. P., Jose M. D., Langham R. G., Lawton P. D., McTaggart S. J., Peake M. J., Polkinghorne K. \& Usherwood T., 2012. - Chronic kidney disease and automatic reporting of estimated glomerular filtration rate: new developments and revised recommendations. Med. J. Aust., 197 (4): 224-235.

22. Kanko F., Manh G.T., Kouadio F., Guingant A., Le Bizec B., N'Guessan Y.T., Pradere J-P., André F. 2000. Détermination structurale des composants extraits de Parkia biglobosa, Journal de la Société Ouest-Africaine de Chimie, 9 : 89-97.

23. Kouadio F., Kanko C., Juge M., Grimaud N., Jean A., N'Guessan.Y.T, Petit J.Y. 2000. Analgesic and antiinflammatory activities of an extrait from Parkia biglobosa used in traditionnal medecine in the Ivory Coast, Phytotherapy Research, 14 : 635-637. 
24. Lawal I., Uzokwe N., Igboanugo A., Adio A., Awosan E., Nwogwugwu J., Faloye B., Olatunji B. \& Adesoza A ; 2010. - Ethnomedicinal information on collation and identification of some medicinal plants in research institutes of SouthWest Nigeria. AJPP ; 4(1) : 1 - 7.

25. Luckow M et Hopkins HC., 1995. A cladistic analysis of Parkia (Leguminoseae : Mimosoideae). American Journal of Botany $82: 1300-1320$ pp.

26. Mukinda J.T. \& Syce J.A., 2007. - Acute and chronic toxicity of the aqueous extract of Artemisia afrain rodents. J. Ethnopharmacol., 112: 138-144.

27. N'Dir B., Vanhentenryck F., Diop M., Hbid C., Jacques P., Cornélius C., Jacques P., Thonart P., Roblan D., 1994. Propriétés antifongiques de la microflore sporulée du nététu. Cahier Agriculture, $3: 23-30$.

28. OCDE, 2001. Lignes directrices de l'organisation de coopération et de développement économiques (OCDE) pour les essais de produits chimiques $n^{\circ} 423$ : toxicité orale aiguëMéthode par classe de toxicité aiguë. 14p.

29. OCDE, 2006. Lignes directrices de l'organisation de coopération et de développement économiques (OCDE) pour les essais de produits chimiques $n^{\circ} 407$ : Etude de toxicité orale à dose répétée pendant 28 jours sur les rongeurs. $14 \mathrm{p}$.

30. Odetola A.A., Akinloye O., Egunjobi C., Adekunle W.A., Ayoola A.O. 2006. Possible antidiabetic and antihyperlipidamic effect of fermented Parkia biglobosa (Jacq) extrat in alloxan-induced diabetic rats, Clinical and Experimental Pharmacology and Physiology, 33 : 808-812.

31. Odunfa,S.A. and Oyewole,O.B.1986. Identification of Bacillus species from « iru », a fermented African locust bean product. J Basic Microbiol, 26, 101-108.

32. Olabinri B.M., Adetutu A., Olaleye M.T., Oluwafunsho B.O., Oyeniyi O.O., 2013. A study of antioxidative potentials of acetone and aqueous of Parkia biglobosa an Tetracarpidium conophorum stem barks in vitro. 369, 368-373.

33. Ouédraogo A. S., 1995. Parkia biglobosa (Leguminosae) en Afrique de l'Ouest: Biosysthématique et Amélioration. Thése doctorat Wageningen an University, Institute for Forestry and Nature Research, IBN-DLO, 205p.

34. Ouoba, L.I.I., Diawara, B., Amoa-Awua,W.K, Traoré, A.S. and Lange Moller, P. 2004. Genotyping of starter cultures of Bacillus subtilis and Bacillus pumilus for fermentation of African locust bean (Parkia Biglobosa) to produce soumbala. Int J Food Microbiol 90, 197-205.

35. Osho I. B., Lajide L., 2012. Prescreening evaluation of some plant extract used in ethno-veterinary practices as anttrypanosomal agents. Journal of Medicinal Plants Research Vol. 6(11) : 2056-2060.

36. Rahman M.F., Siddiqui M.K. \& Jamil K., 2001. - Effects of Vepacide (Azadirachtaindica) on aspartate and alanine aminotransferase profiles in a subchronic study with rats. Hum. Exp. Toxicol., 20: 243-249.

37. Rahman I., Biswas S. K., \& Kode A., 2006. - Oxidant and antioxidant balance in the airways and airway diseases. Eur. J. Pharmacol., 533: 222-539.

38. Rasekh H. R., Nazari P., Kamli-Nejad M., Hosseinzadeh L., 2008. - Acute and subchronic oral toxicity of Galega officinalis in rats. J. Ethnopharmacol., 116(1): 21-26.

39. Risk D., Jurkovitz C. \& Veledar E., 2009. - Quality of life in autosomal dominant polycystic kidney disease patients not yet on dialysis. Clin. J. Am. Soc. Nephrol., 4(3):560-566.

40. Roopashree T. V S., Raman D., Rani R. H. S. \& Narendra C., 2009. - Acute oral toxicity studies of antipsoriatic herbal mixture comprising of aqueous extracts of Calendula officinalis Momordica charantia, Cassia tora and Azadirachta indica seed oil. Thai. J. Pharm. Sci., 33: 74-83.

41. Sanchez-Elsner T., Ramirez J. R, Rodriguez-Sanz F., Varela E., Bernabew C. \&. Botella L. M., 2004. - A cross talk between hypoxia and TGF-beta orchestrates erythropoietin gene regulation through SPI and smads. J. Mol. Biol. 36(1): $9-24$.

42. Tietz N., 1987. - Fundamentals of Clinical Chemistry. Ed WB Saunders Co: Philadelphia, 3: 427p.
43. Tringali C., Spatafora C., Longo O.D. 2000. Bioactive contituents of the bark of Parkia biglobosa, Fitoterapia, 71 : $118-125$.

44. Udut, E., Zhdanov V. V., Gur I., L. A., Minakova M. I. \& Dygai A. M., 2005. - Mechanisms of the erythropoiesisstimulating effect of skullcap (Scutellaria baicalensis) extract. Eksp. Klin. Farmakol., 68: 43-45.

45. Yapo A. F., Yapi H. F., Sangaré M., Ahiboh H., Yayo E., Attoungbré H. M.-L., Edjeme A. N., Latte T., Kassi H., Sawadogo D., Monnet D., Djaman A. J., 2010. Effects of aqueous extract of leaves of Parkia biglobosa in rabbitAgriculture and Biology Journal of North America, 1(6) : $1340-48$. 